\title{
THE COMMON APP
}

\author{
It's in the blood.
}

\section{BY ROBERT SCHERRER}

$\mathrm{B}$ $y$ tradition, Judgement Day always fell on 1 April, although the hour for the actual event had drifted over the years, eventually settling at 6:00 p.m.. Anne Stepanic glanced around the Harringtons' cocktail party, already regretting her decision to attend.

"Anne, come over here," said George Harrington, waving her towards the makeshift bar in the corner of his living room. "What can I get you to drink?"

Anne gazed uncertainly at the row of bottles on the card table. "How about a ... Budweiser?"

"Budweiser? Sorry, don't have any. But I do have a good selection of imported beer. Or maybe a white wine?"

Anne shook her head. "Never mind. I'll just have some water."

"I understand completely, dear," said Vanessa Harrington, sliding in from behind Anne and wrapping her perfectly manicured fingers around Anne's wrist. "We all need to be sober when the big announcements come." Vanessa took a sip from her gin and tonic. "Tell me," asked Vanessa, "where did Larry apply?"

"Well, Eastern Southwest State University, of course. I knew we could afford that. And then I, well ... I thought it would nice to apply someplace, well ... you know, a reach for him, so we sent in an application to Yale."

Vanessa coughed, almost choking on her drink. "Did you say Yale?"

"Yes," said Anne. "What's wrong with that?"

"Nothing wrong with that," said George.

Vanessa glared at her husband. "Well," she said, "it's just that college admissions these days - it's really all a question of the right breeding, isn't it?" Vanessa fingered the strand of pearls around her neck. "And your husband - I would never speak ill of the dead, mind you, but your late husband was a ..." Vanessa paused briefly before delivering her coup de grâce. "He was a plumber."

Anne stuck out her chin. "And a good plumber, too. He was a smart man. But back in the old days, you had to fill out an application for college - not like now, where you just send in a cheek swab. He always said that he just couldn't be bothered to apply."

George tried to change the subject. "Did you know that the gene scan allows them to test for 27 different intellectual abilities?" He chuckled. "I remember some of the dumb questions they asked when I applied for college. 'If you were a breakfast cereal, which one would you be?' It's so much more scientific these days."

Vanessa set her drink down on the bar.

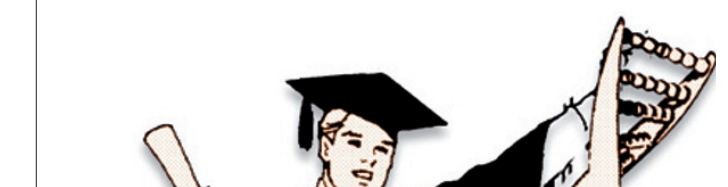

"He's right across the street," said Anne, "visiting Cathy Higgins. They've been spending so much time together lately. It's a shame they probably won't be going to the same school next year. I'm not sure they realize that yet."

To a chorus of vaguely martial music, the wall screen filled with foot-high orange letters, announcing "Judgement

Day". George had already programmed it for the families in attendance, and the screen rapidly split into individual cells. Anne strained to find Larry Stepanic. There he was, in the lower right-hand corner, with 'Yale' spelt out in bright green block letters. Anne suppressed the urge to squeal. She turned to Vanessa, who was slowly turning purple.

"There must be some mistake," said Vanessa, shaking her head. "Harvard - red. Princeton - red. Brown - red."

"Hey, that's funny," said her husband. "Brown red."

Vanessa whirled and poked a finger into George's chest. "Your fault. Your genes. We're ruined. Chester will have to go to some pathetic second-rate state school, and it's all your fault. You stupid, stupid man. Why did I marry you?" Vanessa's voice trailed off in an incoherent rant. "Pathetic specimen of an inferior genetic bad DNA..." Then she shrieked and ran to her bedroom, slamming the door behind her. The other parents in the room stared into their drinks for a decent interval, then began to drift away from the party.

"Well," said George, "I guess we ought to tell the kids, don't you think?"

"I told Larry and Cathy to get over here by
"Eastern Southwest State's a perfectly good school, Anne. And if Larry doesn't get in, they have a northern branch campus that would certainly take him." Vanessa glanced over at George. "Our Chester will be going to Harvard, just like his father."

"But what if he doesn't get in?" asked Anne.

Vanessa shot Anne a poisonous look. "Oh, we've made alternate plans. Princeton is an excellent back-up choice." Vanessa smoothed back her peroxide hair. "Now, George, it's almost time. Be a sweetheart and turn on the wall screen." $\rightarrow$ NATURE.COM

Follow Futures on Facebook at: go.nature.com/mtoodm
"Yes, dear," mumbled George. He flicked his wrist, powering up the far wall. "So, Anne, where is Larry?" 6:05," said Anne.

A few minutes later, the front door opened, and in toddled Larry and Cathy, each one clutching a favourite stuffed animal. Larry cradled his blue hippo, and Cathy dragged a stuffed bunny along the floor by one of its ears.

Anne hugged Larry. "Guess what," she said, "you got into Yale!"

Larry furrowed his brow. "Is that where I'm going to school next year?"

"Oh no, silly," said Anne, smiling. "Next year, you're going to kindergarten." -

Robert Scherrer is chair of the Department of Physics and Astronomy at Vanderbilt University. He has published a number of science-fiction short stories in Analog, and one previous story in Futures. 